\title{
CHESTNUT PESTS IN CENTRAL ITALY
}

\author{
S. Speranza \\ Plant Protection Department \\ University of Tuscia \\ Via S. Camillo De Lellis, \\ 01100 Viterbo \\ Italy
}

Keywords: Curculio elephas, Pammene fasciana, Cydia fagiglandana, Cydia splendana, Oligonychus bicolor, Control, Italy

\section{$\underline{\text { Abstract }}$}

In recent years interest in chestnut (Castanea sativa Mill.) cultivation has increased in Central Italy. Government Research Departments have been requested to address issues concerning plant health in chestnut orchards. The most pressing problem is linked to the presence of phytophages, which directly affect production.

Chestnut quality is the most important feature of saleable production. The main phytophagies affecting this crop have already been identified by researchers as: Curculio elephas Gyll. (Coleoptera, Curculionidae), Pammene fasciana L., Cydia fagiglandana (Zell.), Cydia splendana L. (Lepidoptera, Tortricidae), among which the Curculionidae are the key pests.

In Central Italy there are areas (Vallerano, Viterbo) where C. elephas may attack as much as $90 \%$ of production, compromising the whole yield. The presence of tortrix moths also affects saleable production, but infestation levels are always lower than chestnut weevil levels.

Guided and biological control tests are being carried out in order to contain key pest populations.

\section{Introduction}

The positive economic reappraisal of chestnut has prompted scientific research to develop new pest control methods. The purpose of this study is therefore to provide an overview of the state of the art in Central Italy and propose new integrated control methods against the major chestnut phytophages.

\section{Materials and methods}

\subsection{Study area}

Trials were carried out in two chestnut orchards in the province of Viterbo :

- Chestnut plantation located in the municipality of Soriano nel Cimino (VT), at an average altitude of $670 \mathrm{~m}$.

- chestnut plantation located in the municipality of Vallerano (VT), at an average altitude of $413 \mathrm{~m}$.

In both plantations the most widely represented variety was «Castagna» (Maschio or Velletrana), with sporadic presence of cv. «Marrone» (Bignami, 1990). Trial fields measured roughly two hectares and were surrounded by other chestnut forests. 


\subsection{Chestnut pests}

There are numerous arthropods that can infest table chestnut (Pollini, 1998). In Central Italy the key insect is Curculio elephas Gyll. (Coleoptera, Curculionidae) followed, in order of importance, by the lepidopterans C. splendana, $C$. fagiglandana and $P$. fasciana (Lepidoptera, Tortricidae). Occasionally damages is caused by a mite Oligonychus bicolor (Banks) (Cinti, 1995).

\subsubsection{Chestnut weevil [Curculio elephas (Gyll.) Coleoptera, Curculionidae]}

This insect presents a characteristic long curved rostrum. Its color is yellowish-grey, and it has an elongated oval shape. The length of its body, without the rostrum, is 6-10 $\mathrm{mm}$ on average. In the female the rostrum slightly exceeds the length of the body, while in the male it is noticeably shorter (Colizza, 1928).

The larva, which is apodal, is ivory white. The insect is univoltine, and mainly attacks chestnut, where it feeds on the amydaceous content of the chestnut fruit, but it can also attack acorns of the genus Quercus. In Central Italy the adults appear between the end of August and the month of September (see Tab. 1). Some researchers have explained this staggered time phase by invoking the different burial dates of overwintering larvae, assuming a time gap of 1-2 weeks between larvae buried in October and those buried in November (Menu and Debouzie, 1995). Females lay their eggs by piercing the husk with their rostrum and inserting an egg into the hole. The newly emerged larva penetrates into the underlying chestnut fruit and feeds on the amydaceous substrate of the kernel. As many as 18 larvae per fruit have been reported, although in general each fruit hosts no more than 2 or 3 larvae. Recent studies have shown that the female lays only one egg in $80 \%$ of cases and two eggs in $10 \%$ of cases, the remaining percentage deriving from ovipositions of more than two eggs (Deshouant, 1996). The larva feeds on the chestnut fruit until the end of prediapause development. At the end of the larval stage, the larva pierces the pericarp, then emerges from the fruit through this hole and drops to the ground. In Central Italy the mature larva buries itself at a depth ranging from 5 and $15 \mathrm{~cm}$ (in the Viterbo environments) (Cinti et al., 1993), and builds itself a small earth chamber for overwintering. Diapause begins in October and ends in December (Debouzie et al., 1996). From March onwards, morphogenesis proceeds without interruption, up to the emergence of adults (Menu, $1993 \mathrm{a}$ ). At the beginning of the following summer, 32-56\% of larvae pupate and prepare for emergence, while the remainder will pupate in subsequent years, in gradually decreasing percentages (Menu, 1993 b). The newly emerged adult remains in the soil for a little while, and then moves to the canopy of host trees. Thus the insect completes only one generation a year, although, as mentioned above, some larvae with prolonged diapause may remain in the ground for several years.

The damage caused by this insect may be considerable in certain environments of our region, with infestation rates reaching or even exceeding 90\% (Paparatti and Speranza, 1998 a). Furthermore, analysis of infestation must also take into account the interaction between $C$. elephas e $C$. splendana (Debouzie op. cit.).

\subsubsection{Early Chestnut Tortrix moth [Pammene fasciana L. (Lepidoptera, Tortricidae)]}

This lepidopteran has a wing span of $14-15 \mathrm{~mm}$, and is distinguishable from other tortrix moths by its brighter colors and the pattern of its front wings. This insect is widespread throughout virtually the whole of Europe.

The $P$. fasciana larva causes early fall of the fruit, concurrently with physiological fruit drop at the beginning of development of the chestnut fruits. This accounts for the name of the insect: «early chestnut moth».

$P$. fasciana overwinters as a mature larva in a silk cocoon woven into cracks in the bark on the trunk or on large branches, and only occasionally on the ground. In Italy, chrysalides begin to be found towards the beginning of May,; adults appear 20-30 days 
later. Thus the first adults emerge towards the beginning of June, concurrently with the completed formation of primary aments. Adults show scalar flight, which continues up to the end of July or beginning of August. Flights peak between mid-June and mid-July, roughly two months early than the peak of $C y$ dia splendana flights. Insect activity occurs preferentially at dusk.

The resulting damage consists of desiccation and early fall of infested husks, which can be observed in July and August.

Recent research in Central Italy has shown that even when large numbers of $P$. fasciana are captured, this does not necessarily correspond to infestation of chesnut trees, as reported by Arzone for Northern Italy (Arzone et al., 1993).

2.2.3. Intermediate chestnut tortrix moth [Cydia fagiglandana (Zell.) (Lepidoptera, Tortricidae)]

This lepidopteran has a wing span of $15-20 \mathrm{~mm}$, which bears a striking similarity to that of Cydia splendida; its geographic distribution is also very similar to that of the latter species. This geographic distribution corresponds to that of beech (Fagus Sylvatica L.), to which this moth is closely linked. Its presence has also been reported in hazel nuts (Corylus avellana L.), in the fruits of holly oak (Quercus ilex L.) and in other types of oak (Russo, 1947). Three years of research in Campania have shown that the majority of infested chestnuts are attacked by C. fagiglandana (Rotundo et al., 1991).

\subsubsection{Late chestnut tortix moth [Cydia splendana $\mathrm{Hb}$. (Lepidoptera, Tortricidae)]}

The adult has a wing span of $16-19 \mathrm{~mm}$. The young larva is white while the adult is whitish or slightly pink, with a length of $15-17 \mathrm{~mm}$. This species has been reported in central and southern Europe. In Italy it is found predominantly in the northern regions.

The adults, in Central Italy, emerge from mid-August up to September, and lay their eggs on chestnut husks. Usually one only larva penetrates into each chestnut fruit, although two or even three are not infrequently found.

Many fruits fall while still unripe, while others may succeed in ripening and are then harvested as part of the crop. When the larva reaches maturity it pierces the pericarp and emerges from the chestnut fruit, burrows into the ground and when it reaches a certain depth, it encloses itself in a cocoon constructed by solidly binding soil particles together. They overwinter in the cocoon and are transformed into chrysalides only in the following June.

In the Viterbo area this insect is present, but infestation levels appear to be low and thus do not appreciably affect product marketing.

In 1940 several parasitoids were identified: Ascogaster quadridentatus Wesm. (braconid), Phanerotoma dentata Panz. Var flavescens (braconid), Microdus tumidulus Nees (braconide), Pristomerus vulnerator (Panz.) (ichneumonid) (Russo op. cit.)

\subsection{Sampling methods}

No sampling methodologies are known for the chestnut weevil. Several new systems have been tested, some of which derive from sampling methods used for other curculionids. The first method consists shaking the branches, while the second makes use of the new American pyramid traps. The results of these methods have clearly shown the difficulties involved in studying the bioethology of this insect. These methodologies will be discussed in greater detail in future papers.

Pheromon traps supplied by the firm ISAGRO were used (Trap Test) for the three tortricid lepidopterans. 


\section{$\underline{\text { 3. Results }}$}

\subsection{Weevil control methods}

Recent research has made it possible to engage in detailed study of control of this harmful insect.

\subsubsection{Agronomic control systems}

\subsubsection{Nets beneath the canopy}

Tests were conducted on several «biological» control methods designed mainly to prevent burial of mature larvae in soil. The intervention consisted in early and scalar harvesting of the fruits, together with the use of appropriate nets. We used white nets weighing $150 \mathrm{gr} / \mathrm{m}^{2}$, with 160 warp threads and 60 weft threads, with a width of roughly $130 \mathrm{~m}^{2} /$ plants. The nets were carefully placed beneath the projection of the canopy of trees previously found to be severely infested. Given the mesh size, their main function was to prevent the fallen larvae from entering the soil. This technique was applied for two years in a plot measuring roughly $2 \mathrm{ha}$; results were found to be rather effective, reducing infestation percentage from $90 \%$ to $40 \%$ (Paparatti, private communication). However, this substantial reduction of the infestation is not yet sufficient to guarantee profitable marketing of the chestnuts.

\subsubsection{Mechanized harvesting}

This innovative harvesting system, repeated several times, prevents the mature larvae still present in the fallen fruit from entering the soil. This technique makes it possible to achieve a marked decrease in the number of larvae that succeed in burrowing into the ground and overwintering, thereby reducing the overall population present in the chestnut grove. Further research is required to evaluate the production costs.

\subsubsection{By biotic agents}

\subsubsection{With pathogens}

Underground larva mortality has been found in France to be in excess of 50\%, even in laboratory conditions in which the concurrent presence of predators can be excluded. This decrease in the hypogeal population is almost certainly attributed to the presence of predator entomopathogenic fungi such as Beauveria bassiana and Metarhizium anisopliae (Menu and Debouzie op. cit.). As early as 1943 DOBOS reported that the weevil could be infected by $M$. anisopliae (DoBos, 1943). In Central Italy the natural hypogeal mortality rate has been shown to exceed $70 \%$, caused, as in France, essentially by pathogens (Paparatti and Speranza 1998 b). In 1989 a 97\% infestation rate by the entomopathogen $B$. bassiana was found on $C$. elephas larvae in chestnuts collected in the province of Catanzaro (Rotundo et al., 1989).

In the natural environment the action of micromammals (Talpa europea L. and Apodemus sylvaticus L.), of predators (Scolopendra cingulata Laitrelle and Lithobius forficatus (L.)) and of parasitoids such as the Braconid and Icneumonid Hymenoptera is also observed, but is not easily quantifiable (Menu and Debouzie, 1993).

\subsection{Tortrix Control Methodologies}

In Central Italy pest control methods against $P$. fasciana are not recommended, since its presence does not significantly affect production. But as regards to $C$. fagiglandana and $C$. splendana, which are found directly on the fruits at harvest time, pest control 
techniques applied against the weevil also act as a limitation on the presence of the above pests.

Any rational pest control method must necessarily take into account the manner in which the pests overwinter. In the case of young chestnut trees with smooth bark, almost the total number of $P$. fasciana larvae can be captured by setting corrugated carton bandtraps on the trunk and large branches.

In the province of Catanzaro, 24\% percentage of parasitization of these larvae by the Braconid Hymenopteran Ascogaster quadridentatus Wesm. was observed in 1984 (Rotundo et al., 1991).

In the province of Potenza, mature larvae of $P$. fasciana were captured that showed $65 \%$ parasitized by the fungus Paecilomyces farinosus (Holm. Gray) (Nanni et al., 1988).

\section{Discussion}

The notable complexity of the chestnut ecosystem (Vitagliano et al., 1993), which shares some of the features of an agro-ecosystem but also of a forest ecosystem, leads to considerable risk when applying chemical control using the active ingredients currently registered for chestnut crops. Unsuitable chemical treatment leads to undesirable simplification of the ecosystem, which in turn allows an increase in normal phytophage infestation but also in occasional phytophages such as the chestnut mite (O. bicolor).

Analyses carried out in the Monti Cimini area have shown that the key insect affecting table chestnut is the curculionid $C$. elephas, followed by the tortrix moths, with $C$. fagiglandana representing the greatest risk, and additionally $C$. splendana and finally $P$. fasciana.

Within the European context, it is therefore necessary to carry out coordinated research designed, first, to evaluate the key chestnut insects present in Italy, and subsequently to coordinate integrated control strategies. Studies are in progress in Italy also designed to evaluate the possibility of using biological insecticides for control of the weevil, such as entomopathogenic fungi and other organisms that are non-toxic for man.

\section{Acknowledgements}

Work supported by the grant of the Mountain Community of Monti Cimini «Programma di indagini ed interventi per la messa a punto di tecniche di lotta contro le principali avversità del castagno nel comprensorio dei Cimini».

\section{$\underline{\text { References }}$}

Arzone A., Alma A., Tavella L., Bonelli S., Galliano A., Ascheri B. 1993. Indagini sui principali insetti delle castagne delle coltivazioni piemontesi. Atti International Congress on Chestnut, October 20-23, 1993: 617-620.

Bignami C. 1990. La classificazione varietale del Castagno dei Monti Cimini. Economia Montana 5: 43-45.

Bovey P., Linder A., Müller O. 1975. Researches sur les insectes des châtaignes au Tessin (Suisse). Schweiz Z. Forst, 126: 781-820.

Cinti S., Paparatti B., Storti C., Vitagliano A. 1993. Results of the two year period (19911992) on the bioethology of Curculio elephas (Gyll.) (Coleoptera, Curculionidae) in the chestnut tree orchards of Monti Cimini (Viterbo - Italy). Atti International Congress on Chestnut, Spoleto (Italy), October 20-23, 1993. pp. 621-624.

Cinti S., Nannelli R., Paparatti B., Storti C., Vitagliano A. 1995. Prime osservazioni sulla biologia di Oligonychus bicolor (Banks) (Acari, Tetranychidae) nel comprensorio castanicolo dei Monti Cimini. Inf. Fitopatologico 1995/3: 60-62.

Colizza C. 1928. Contributo alla conoscenza del Balanino delle castagne (Balaninus elephas: Insecta Coleoptera). Boll. Lab. Zool. Gen. Agr. (Portici). 22: 244-262. 
Debouzie D., Heizmann A., Desouhant E., Menu F. 1996. Interference at several temporal and spatial scales between two chestnut insect. - Oecologia (1996), 108: 151-158.

Desouhant E. 1996. Le ponte chez le balanin de la chataigne, Curculio elephas Gyll. (Coleoptera: Curculionidae). Ann. Soc. Entomol. Fr., 199632 (4): 445-450.

Dobos L. 1943. Gesztenyetermésünic effenségei (Feinde unseres Kastanienertrages). Növényvédelem 19: 174-176.

Menu F. 1993a. Diapause development in the chestnut weevil Curculio elephas. Entomol. Exp. Appl. 69: 91-96.

Menu F. 1993b. Strategies of emergenze in the chestnut weevil Curculio elephas (Coleoptera: Curculionidae). Oecologia (1993), 96: 383-390.

Menu F., Debouzie D. 1993. Coin-flipping plasticity and prolunged diapause in insect: example of the chestnut weevil Curculio elephas (Coleoptera: Curculionidae). Oecologia, 93: 367-373.

Menu F., Debouzie D. 1995. Larval development variation and adult emergence in the chestnut weevil Curculio elephas Gyllenhal (Col., Curculionidae). J. Appl. Ent. 119: 279-284.

Nanni B, Rotundo G, Marziano F. 1988. Paecilomyces fumosoroseus (Wize) Brown et Smith e $P$. farinosus (Hol ex S.F. Gray) Brown at Smith due funghi entomopatogeni poco noti in Italia e loro nuovi ospiti. Ann. Fac. Sci. Agr. Univ. Napoli-Portici 22: 3749.

Paparatti B, Speranza S. 1998 a. I principali fitofagi del castagno. In Introduzione di nuove tecniche di raccolta a minore impatto ambientale per la valorizzazione della castanicoltura da frutto nel territorio dei monti Cimini. «Giornata di studio sul castagno da frutto», Caprarola gennaio 1998: 67-81.

Paparatti B., Speranza S. 1998 b. Biological control of chestnut weevil (Curculio elephas Gyll; Coleoptera, Curculionidae) with the entomopathogen fungus Beauveria bassiana (Balsamo) Vuill. (Deuteromycotina, Hyphomicetes). In press.

Pollini A. 1998. Manuale di entomologia applicata. Edagricole, Calderini pp.1462.

Rotundo G, Nanni B., Marziano F. 1989. Curculio elephas Gyll., nuovo ospite per l'Italia del fungo entomoparassita Beauveria bassiana (Bals.) Vuill. Annali Fac. Scienze agrarie Univ. Napoli, Portici. 13: 77-82.

Rotundo G., Giacometti R, De Cristoforo A. 1991. Sulla dannosità dei principali fitofagi del frutto del castagno in alcune aree dell'Italia meridionale. Atti XVI Congr. Naz. Ital. Ent. Bari - Martina Franca 23-28 settembre: 771-779.

Russo G. 1947. Studio morfo-sistematico delle tortricidi delle castagne. Annali della Facoltà di Agraria Università di Pisa, Pisa. 8: 1-47.

Vitagliano A., Storti C., Cinti S., Paparatti B 1993. First contribution to the knowledge of the arthropods of the chestnut tree orchard (Castanea sativa Mill.) in the Monti Cimini (Viterbo, Italy). Atti International Congress on Chestnut, Spoleto (Italy), October 2023, 1993. pp. 635-638. 
Table 1. Biology of Curculio elephas in Central Italy

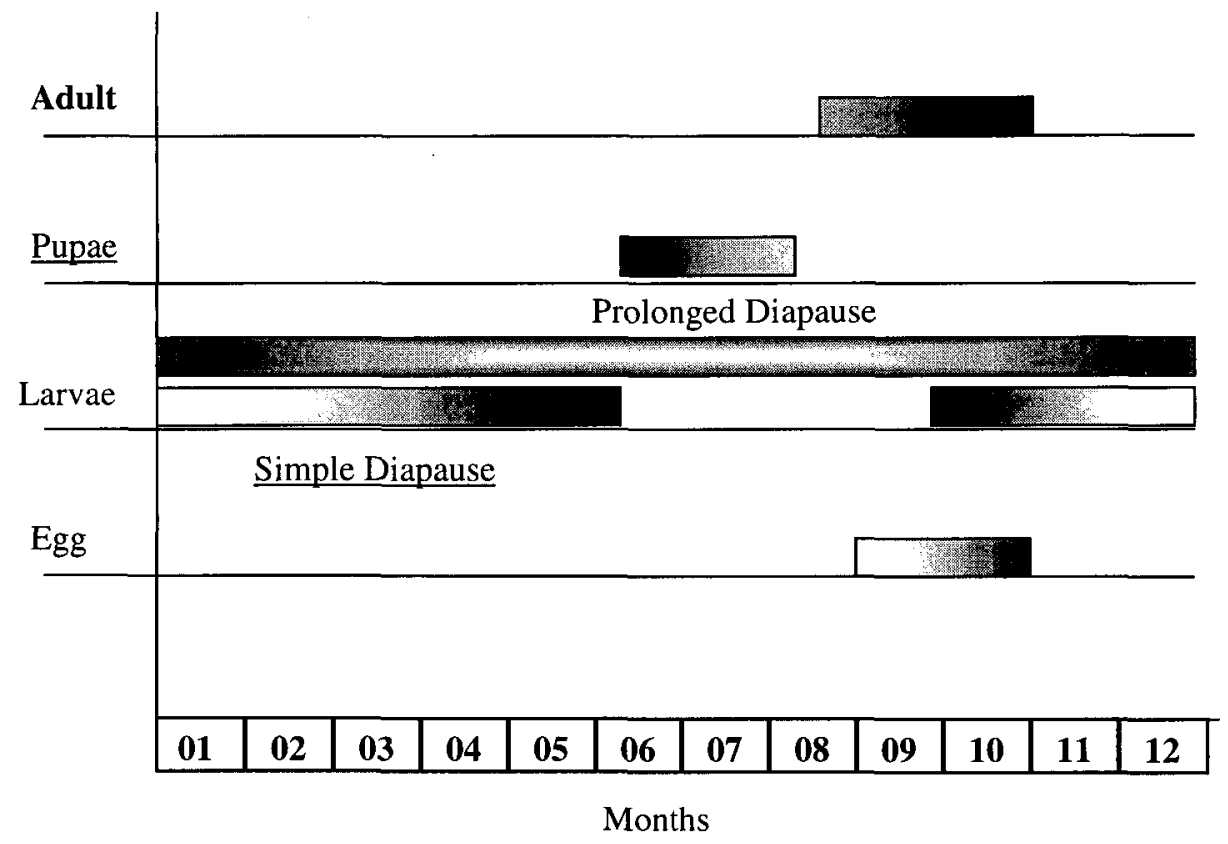

